\title{
Exploration of Fine Motor Skills through the Application of Paint
}

\author{
Dewi Mike Oktavia ${ }^{1}$, Muhammad Mushfi El Iq Bali ${ }^{2}$, Handono Fatkhur Rahman ${ }^{3}$, Umar $^{4}$, \\ Agus Syakroni ${ }^{5}$ and Faizatul Widat ${ }^{6}$ \\ Islamic Faculty, Nurul Jadid University, Paiton, Probolinggo, Indonesia ${ }^{1}$ \\ Islamic Faculty, Nurul Jadid University, Paiton, Probolinggo, Indonesia ${ }^{2}$ \\ Faculty of Health, Nurul Jadid University, Paiton, Probolinggo, Indonesia ${ }^{3}$ \\ Tarbiya Faculty, Islamic Institute of Muhammadiyah Sinjai, Indonesia ${ }^{4}$ \\ Tarbiya Faculty, Institute of pesantren Mathali'ul Falah, Pati, Indonesia ${ }^{5}$ \\ Islamic Faculty, Nurul Jadid University, Paiton, Probolinggo, Indonesia ${ }^{6}$

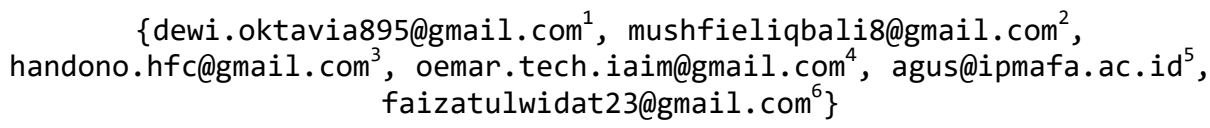

\begin{abstract}
This study aims to prove the influence of paint applications on children's fine motor skills through coloring activities. This study uses a quasiexperimental design quantitative research design with a pretest-posttest controlled group design model. Learning in the control group used a conventional model in the form of a picture book while the experimental group applied the paint application. The study was conducted at the Mentoring State Kindergarten with research subjects 30 children for the control group and 30 children for the experimental group. The results showed that the experimental class children using the paint application had a higher average compared to the control class that used the conventional model in the form of a picture book. The average number of the experimental class is 83.25 , and the average number of the control class is 76 . Based on the data analysis that has been done that t-test $>$ $\mathrm{t}$ table, which is $2.161>2.07387$. Thus it can be concluded that the application of paint affects the fine motor skills of early childhood.
\end{abstract}

Keywords: Paint Application, Fine Motor Ability, Coloring Activity.

\section{Introduction}

The rapid development of advances in computer technology affects all aspects of people's lives in various fields, one of which is in the field of education [1]. According to Knapp stated that most teachers use computer learning to support their learning through models of communication, education, computers is one of the efforts to renew education included in the teaching-learning process [2]. In the field of education not only functions for teaching and learning activities carried out by teachers but also useful for children.

Benny stated that computer technology could and should have been taught from an early age, the development of computer technology will be increasingly rapid which requires 
students to be more familiar with and even able to utilize the technology in their life activities $[3]$.

At the level of early childhood education, computers can be introduced both hardware components such as monitors, CPU, mouse, keyboard (hardware). Of course, children and teachers also need to be introduced to software and their uses, such as running Microsoft Word, Microsoft Paint (paint application) programs, etc [4]. Early childhood is a child in the age range of birth to six years [5].

Ramli revealed that during this period it was the most effective period for developing the potential in developing aspects of its development, which included the development of habituation (religious and moral values, social, emotional, and independence), language, cognitive, motoric and artistic [4].

The motor development is divided into two, namely fine and gross motor [6]. Sumantri Fine motoric abilities of children can develop even if they do not get stimulation, but the development or ability achieved by children cannot be maximized or only reaches the minimum limit [7].

One of the learning activities that is often done in kindergarten to develop fine motor skills is coloring. The activity of coloring pictures is an activity that provides opportunities for students to carry out the task of coloring pictures based on direct instructions from the teacher. The method of giving assignments to color drawing is very useful for improving children's fine physical motor skills [8].

\section{Literature review}

\subsection{Paint Application}

The paint application on the computer is one of the image processing software; paint application is one of the default applications from Microsoft Windows [4]. Microsoft Paint or called MS Paint or Paint is a simple graphics or drawing application that has been installed in all versions of Microsoft. Windows MS. Paint is given the ability to draw, color, and edit images or photos that have been taken using a digital camera. MS Paint also plays an active role in licensing editing images of monitors that have been taken using the "Print Screen" keyboard [9].

So the Windows program is always an image processing application that is painted. Each window display paint application is different, but in principle, the way to use it is the same. The steps to run the paint application are as follows: 1) Open the Microsoft paint application by clicking the start button on the taskbar; 2) Click the all program menu, accessories, paint; 3) The paint window will be displayed [3].

\subsection{Fine Motor Skills}

Kindergarten education institutions have a goal to help develop children's abilities, one of which is the fine motor skills of children; kindergartens must be able to provide quality human resources (educators) and infrastructure that can support the purpose of education in kindergarten [10]. According to Suyanto the characteristics of children's fine motor development are more emphasized in more specific body movements such as writing, drawing, cutting and folding [11].

Moeslichatoen explained that children's fine motoric physics is a movement that uses smooth muscles or certain parts of the body that are influenced by opportunities to learn and 
practice, for example, the ability to move objects by hand, scribbling, arranging blocks, cutting, writing, matching images and more so on [12].

Mahendra stated that fine motor skills are skills that require to control small muscles to achieve successful implementation of skills [10]. Hurlock states that fine motorist is a movement that uses smooth muscles or certain parts of the body, which are influenced by the opportunity to learn and practice [13]. Susanto reveals that fine motorist is a subtle motion involving only certain parts of the muscles. Only, because it doesn't need power. However, this smooth motion requires fast coordination [14].

Based on the explanation it can be concluded that fine motor is an ability that requires movement of the skills of small muscles in the body such as the skill of using fingers and wrists and good hand-eye coordination [7]. The benefits of fine motor skills in kindergarten children are to practicing fine motor coordination skills of hand, and eye coordination can be developed through painting activities.

The few examples of fine motor skills are: grasping, inserting objects into holes, turning pages or sheets of books, imitating lines, drawing, folding, cutting, sticking, stringing, and arranging (constructive games) [15].

\subsection{Coloring Activities}

Coloring activities are quite favorite activities for children, especially for children who are just learning to recognize colors. In this activity, children are given the freedom to choose colors and combine colors. The coloring is a skill that is liked by children. The coloring is also a medium for them to pour out all their imagination and inspiration about everything that they might have touched or experienced [8].

According to Hajar stated that coloring activities would invite children how to direct children's habits in spontaneously coloring into the habits-the habit of pouring colors that have educational value [16].

Children in kindergarten like coloring activities using various ingredients. Coloring activities are coloring activities carried out using a variety of media such as crayons, markers, colored pencils, and food coloring. Therefore, at the age of childhood kindergarten is very appropriate to improve children's fine motor skills through coloring activities so that the fine motor skills of children are more mature [17].

\section{Method}

Based on the problems examined, namely the effect of the application of paint on fine motoric abilities through coloring activities in the State Kindergarten Pembina City of Probolinggo, the form of this research is quantitative, with the type of research QuasiExperiment (quasi-experimental). The population in this study were all group B State Kindergarten Pembina City of Probolinggo. The State Kindergarten Pembina City of Probolinggo has a total of 60 students. The sampling technique in the study was purposive sampling technique. Samples in this study were grouped B1 and B2. Group B1 was used as an experiment and group B2 was used as a control group. The number of samples for each child was group B1 as many as 30 children as the experimental group and group B2 30 children as a control group.

Collection techniques the data used in this study is a teacher-made test. The test is said to be valid if the test can measure what you want to measure. This instrument uses a checklist format for its assessment. With the evaluation criteria, which are Very Good Developing given 
a score of 4, Developing according to Expectations given a score of 3, Starting to Develop 2, Not developing 1. Any data analysis technique used in this study is comparing the differences between the two averages value so that it is done by $t_{\text {-test }}$. But before that, first, do normality test and homogeneity test. Before analyzing the difference, it is necessary to do a normality test with liliefors test, and homogeneity test with Barlett test. If it is known that a data is normally distributed and homogeneous, then the data analysis is carried out according to the analysis technique that has been carried out, namely by looking for a comparison using the ttest.

\section{Result and discussion}

The data described in this study consisted of two groups, namely data about the results of the pre-test in the experimental group (B1) and in the control group (B2) on the fine motor skills of children before treatment.

Table 1. Recapitulation of the Results of Pre-test for Fine Motor Ability of Children in Experimental Classes and Control Classes

\begin{tabular}{lll}
\hline Variable & Experimental Learning B1 & Control Learning B2 \\
\hline $\mathrm{N}$ & 30 & 30 \\
Highest Score & 75 & 75 \\
Lowest Score & 50 & 50 \\
Total Score & 790 & 735 \\
Median & 67.5 & 64.5 \\
Average & 65.8 & 61.2 \\
$\mathrm{SD}$ & 6.06 & 8.1 \\
\hline
\end{tabular}

Based on the table above, the experimental class with the number of 30 children obtained the highest score of 75 and the lowest value of 50. From the values of the children of this experimental class, the overall score was 790 median 69.5 with an average value of 65.8 standard deviations 6.06 While the control class with the number of children 12 got the highest score of 75 and the lowest value of 50. From the value of the children of this control class, the overall score was 735 , median 64.5 with an average value of 61.2 standard deviation 8.1 .

Table 2. Recapitulation of Results of Fine Motor Ability Tests of Children in Experimental Groups and Control Groups

\begin{tabular}{lll}
\hline Variable & Experimental Learning B1 & Control Learning B2 \\
\hline $\mathrm{N}$ & 30 & 30 \\
Highest Score & 95 & 85 \\
Lowest Score & 70 & 65 \\
Total Score & 975 & 895 \\
Median & 83.25 & 81.2 \\
Average & 81.2 & 74.5 \\
SD & 8.1 & 6.60 \\
\hline
\end{tabular}


Based on table 2 above, the experimental class with 30 children had the highest score of 95 and the lowest value of 65 . From the experimental values of the children, the total score was 975 , median 83.25 with an average value of 81.2 standard deviations 8.1 . While the control group with the number of children 30 people got the highest score of 85 and the lowest value of 65 . From the value of the children of this control class, the overall score was 895 , median 76 with an average value of 74.5 standard deviations 76 .

So that the results of the children's study were fine motoric abilities of the children in the experimental group and the control group, the results showed that the fine motor skills of children in the experimental group (group B1) were higher than in the control group (group B2).To test the hypothesis t-test is used. From the results of hypothesis testing using the t-test the following results are obtained:

Table 3. Pre-test Calculation Results Test with t-test

\begin{tabular}{lllllll}
\hline No & Group & $\mathrm{N}$ & Average Results & $\mathrm{t}_{\text {-test }}$ & $\mathrm{t}_{\text {table }} \alpha 0,05$ & Decision \\
\hline 1 & Experiment & 30 & 65.8 & \multirow{2}{*}{1.513} & \multirow{2}{*}{2.07387} & Acceptance \\
2 & Control & 30 & 61.2 & & & H0 \\
\hline
\end{tabular}

Viewed from the table above for the real level $\alpha=0.05(5 \%)$ with df of 22 is $=2.07387$. Thus, it can be seen that at the real level $\alpha=0.05(5 \%)$, $\mathrm{t}$-count is smaller than $\mathrm{t}$ table $(0.6215<2.07387)$. Then it can be concluded that there is no significant difference between the fine motor skills of children in the experimental and control classes in the pre-test scores.

Table 4. Results of Calculation of Liliefors Post-Test Testing Experiments and Control Groups

\begin{tabular}{lllllll}
\hline No & Group & $\mathrm{N}$ & $\alpha$ & $\mathrm{L} 0$ & $\mathrm{Lt}$ & Explanation \\
\hline 1 & Experiment & 30 & 0.05 & 0.167 & 0.242 & Normal \\
2 & Control & 30 & 0.05 & 0.168 & 0.242 & Normal \\
\hline
\end{tabular}

Based on the table above it can be seen that the experimental group value of L-test 0.167 is smaller than L-table 0.242 for $\alpha 0.05$. Thus the value of the experimental class comes from data that is normally distributed. For the control class, L-test 0.168 is smaller than L-table 0.242 for $\alpha 0.05$. This means that the control class data comes from data that is normally distributed.

\section{Conclusion}

Based on the results of data analysis that has been done, so it can be concluded as follows: Based on the results of research conducted in State Kindergarten Pembina City of Probolinggo results of fine motor skills of children in the experimental class (B1) with paint applications higher than the control class children (B2) with conventional activities of picture books, (83.25) for the experimental class and (76) for the control class.

\section{References}

[1] C. Muali, S. Islam, and M. M. E. I. Bali, "Free Online Learning Based On Rich Internet Applications; The Experimentation Of Critical Thinking About Student Learning Style," J. Phys. Conf. Ser., vol. 1114, pp. 1-6, 2018.

[2] L. Ayu Aprilia Pangestu Putri, M. Syukri, "Pembelajaran Pengenalan Komputer di Taman Kanak-kanak Islam Al Azhar 21 Pontianak Tenggara," J. Pendidik. dan 
Pembelajaran Untan, vol. 6, no. 8, 2017.

[3] Marisa and D. Setiawan, "Kompetensi Guru dalam Pemanfaatan Komputer untuk Meningkatkan Kualitas Pembelajaran Anak Usia Dini," in Prosiding Temu Ilmiah Nasional Guru, 2016, no. VIII, pp. 455-466.

[4] T. Hayati, M. Kurniawati, and R. Witarsa, "Meningkatkan Kemampuan Kecerdasan Visual melalui Aplikasi Paint," J. Obs. J. Pendidik. Anak Usia Dini, vol. 2, no. 1, pp. 109-116, 2018.

[5] M. W. and I. M. Syaiful Islam, Hasan Baharun, Chusnul Muali, Moh. Idil Ghufron, Mushfi el Iq Bali, “To Boost Students' Motivation and Achievement through Blended Learning," J. Phys. Conf. Ser., vol. 1114 01204, pp. 1-11, 2018.

[6] Ş. ASLAN, "An Evaluation of Fine and Gross Motor Skills in Adolescents with Down Syndromes," Int. J. Sci. Cult. Sport, vol. 4, no. 16, pp. 187-187, 2016.

[7] N. Fadhilah, "Meningkatkan Kemampuan Motorik Halus Melalui Kegiatan Mewarnai Pada Anak Kelompok B Di TK Ar-Rahma Muara Badak Pada Tahun Ajaran 2015 / 2016," Res. Learn. Early Child. Educ., vol. 8, no. 33, p. 44, 2014.

[8] N. S. Murdiani, "Pengaruh Kegiatan Mewarnai Gambar Dalammeningkatkan Motorik Halus Anak Di Kelompok B TK Jaya Kumara Desa Balinggi Jati Kecamatanbalinggi Kabupaten Parigi Moutong,” Bungamputi, vol. 2, no. 3, pp. 106-114, 2012.

[9] B. Ayu and A. Riffadewi, "Mengenal Aplikasi Microsoft Paint Serta Fungsi-Fungsi Yang Terdapat Pada Aplikasi: Pendahuluan Pembahasan Sejarah Microsoft Paint," Ilmu TI. [Online]. Available: http://ilmuti.org/2018/02/23/mengenal-aplikasimicrosoft-paint-serta-fungsi-fungsi-yang-terdapat-pada-aplikasi-microsoft-paint/.

[10] M. Rezaee, N. Mirzakhani, M. Tabatabaee, and L. Dehghan, "The Relationship Between Fine Motor Skills and Social Development and Maturation," Iran. Rehabil. J., vol. 15, no. 4, pp. 407-414, 2018.

[11] L. Indraswari, "Peningkatan Perkembangan Motorik Halus Anak Usia Dini Melalui Kegiatan Mozaik di Taman Kanak-kanak Pembina Agama,” J. Pesona PAUD, vol. 1, no. 1, pp. 1-13, 2012.

[12] E. Sari, "Peningkatan Perkembangan Motorik Halus Anak Melalui Kegiatan Kolase Dari Bahan Bekas Di Taman Kanak-Kanak Aisyiyah,” J. Pesona PAUD, vol. 1, no. 1, pp. 1-11, 2012.

[13] A. Ali, D. Pigou, L. Clarke, and C. Mclachlan, "Literature Review on Motor Skill and Physical Activity in Preschool Children in New Zealand," Adv. Phys. Educ., vol. 7, pp. 10-26, 2017.

[14] R. Kusumastuti, "Meningkatkan Motorik Halus Anak Usia Dini Melalui Kegiatan Origami Pada Anak Kelompok A Roudlotul Athfal (RA) AL-IKHLAS Semarang Barat," Universitas Negeri Semarang, 2014.

[15] M. M. E. I. Bali, "Model interaksi sosial dalam mengelaborasi keterampilan sosial," Pedagog. J. Pendidik. Islam, vol. 4, no. 2, pp. 211-227, 2017.

[16] N. Meylinie, "Pembelajaran Mewarnai Gambar Untuk Meningkatkan Kemampuan Motorik Halus Pada Anak Usia 5-6 Tahun," J. Pendidik. dan Pembelajaran, vol. 6, no. 11 , pp. 1-8, 2009.

[17] I. Apriati and W. Puteri, "Meningkatkan Kemampuan Motorik Halus Melalui Kegiatan Mewarnai di Kelompok B TK KKLKMD Sedyo Rukun Bambanglipuro Bantul," Universitas Negeri Yogyakarta, 2016. 